\title{
製紙技術改善の歩み(10) \\ My Remembrance of Improvement for Paper Making
}

紙パルプ技術協会 会長 西済 口述

米谷稔 記述

J. TAPPI Chairman; Itsuki Nishi

\section{抄紙 機 の 改良・進歩}

\section{まえがき}

今回は我が国洋紙の創業時代から, 戦時体制（昭和 13年頃）に至る間，抄紙機（長網式を主とし，円網式， ティシュー, ヤンキー, 板紙抄造機, パルプマシンを も含めて）の改良，進歩の跡をたどることとし，31工 場を例にとり，述べてゆく。

創業時代，明治時代，大正時代，昭和時代に分け， 年代順に述べることとし，先ずその時代の代表的抄紙 機を有していた会社・工場を抜翠して列記した。

次に抄紙機の構成を示すため，先ず抄紙機の種類， 抄速, 網幅, 抄造品種を述べ, 更に, スクリーン, ワ イヤーパート, プレスパート, ドライパート, 仕上, 運転方式, 特長（工場で採用した特記事項）の順にそ のデータを示した。最後に抄紙機のメーカーを付記し た。

\section{創 業 時 代}

(1) 明治 6 年神戸製紙所

構成 円網抄紙機 網幅 $72^{\prime \prime}$ メーカー 米国 ライスバートン社

(2) 明治 7 年 三田製紙所

構成 円網抄紙機 網幅 $57^{\prime \prime}$ メーカー 米国 ライスバートン社

(3) 明治 7 年 12 月 有恒社 長 網抄 紙 機

構成 網幅 $60^{\prime \prime}$ 書籍用紙 プレス $\cdots 2$ 基, ドライヤー $3^{\prime}-6^{\prime \prime} \cdots 11$ 本

カレンダー 2 本立 $\cdots 2$ 基

メーカー 英国 アン・ファーストン社

特長 我国最初の機械漉洋紙の製造を開始
(4) 明治 8 年紙幣寮抄紙局，後の印刷局抄紙部 構成 円網抄紙機網幅 54" メーカー 国産 印刷局

明治 時代

６）明治 8 年 7 月 王子製紙・王子工場

\section{長 網 抄 紙 機}

構成 網幅 $78^{\prime \prime}$ ，印刷用紙

$$
\begin{aligned}
& \text { ワイヤー } 78^{\prime \prime} \times 30^{\prime} \text { ，テーブルロール } 113 / 16^{\prime \prime} \\
& \text { クーチロール 上段 } 131 / 2^{\prime \prime} \text { (ジャケット巻) } \\
& \text { 下段 } 141 / 2^{\prime \prime} \\
& \text { プレス…2 基 上段 } 131 / 2^{\prime \prime} \\
& \text { 下段 } 141 / 2^{\prime \prime}
\end{aligned}
$$

乾燥蒸気は表側から入って, ドレーンは裏側へ排出 されるよらになっていた。

$$
\begin{array}{ll}
\text { カレンダー } & 2 \text { 本立 } \cdots 2 \text { 基 } \\
\text { リール } & 4 \text { 本巻回転式 }
\end{array}
$$

運転方式 運転方式は，各部ともべルト掛けで並列運 転であった。

特長 漉幅を決定するため, デッケルストラップがあ ったが，材質は不明であった。下段プレスはゴム巻で あったかどらかも不明。

スタッフボンプはダイヤフラム式が使用された。 メーカー 英国製
６）明治20年 7 月＼cjkstart東京板紙・千住工場 長網板紙抄造機

構成 網幅 $74^{\prime \prime}$

プレス $\cdots 2$ 基, ドライヤー $4^{\prime} \cdots 20$ 本

特長 長網式であったので，厚物の抄造には不向きで あったため, 貼合せ, 乾燥室で乾燥し, 亜鉛板にはさ んで,プレートカレンダーで仕上げを行なった。我国 
で最初の板紙抄造機である。

メーカー 英国 バートラム社

（7) 明治22年12月王子製紙・気田工場

\section{円網ヤンキー抄紙機}

構成 網幅 $72^{\prime \prime}$

スクリーン 8 枚プレートのゴーザム式

円網 幅 $72^{\prime \prime}$, 径 $30^{\prime \prime}$, クーチロール $18^{\prime \prime}$

プレスロール 上段 $135 / 8^{\prime \prime}$ (ブロンズ)

下段 $143 / 4^{\prime \prime}$ (ヨ゙ム巻)

スクイズロール $71 / 2^{\prime \prime}$ ，ドライヤー $5^{\prime} \cdots 1$ 本

特長 我国最初の円網ヤンキー抄紙機と考えられる。 メーカー 東京市本所緑町 小㙨機械製作所

（8) 明治23年 王子製紙・王子工場

\section{長 網 抄 紙 機}

構成 抄速 $200^{\prime} /$ 分, 網幅 $84^{\prime \prime}$, 書籍用紙

スクリーン 8 枚プレートのゴーザム式 $\cdots 2$ 基

ワイヤー $84^{\prime \prime} \times 40^{\prime}$ ，テーブルロール $21 / 2^{\prime \prime}$

サクションボックス $\cdots 3$ 本 (面は桂板)

クーチロール 上段 $18^{\prime \prime}$ (ジャケット巻)

下段 $16^{\prime \prime}$ (ブロンズ)

プレス…2 基 上段 $18^{\prime \prime}$ (ブロンズ)

下段 $161 / 2^{\prime \prime}$ (ゴム巻)

フェルトは第 2 プレスで反転した。

ドライヤー上段 $36^{\prime \prime} \cdots \cdots 8$ 本

下段 $48^{\prime \prime} \cdots \cdots$. 本

給気並びにドレーン抽出は何れも裏側で行なわれた。

ドレーンの抽出はサイフォン式であった。

カレンダー 7 本立 $\cdots 2$ 基

リール 2 本巻回転式

運転方式 マーシャル・ドライブで, フリクション・ クラッチが付設されていた。歯車は大きい方は鋳鉄製, 小さい方は，消音のため，ブロンズ製であった。

4 弁式の汽機運転で, 変速にはステップ及びコーンプ リーが使用された。

特長 抄幅を決定するため, ゴム製のデッケルストラ ップが使用された。

テーブルロールの上にスライスを設置し，フローボッ クスからスライス迄は，エプロンシートを敷き，水洩 れを防いだ。スライス 2 枚を使用し，この間で紙料の 超流を起こさしめ, 繊維の分散をはかった。

また，ワイヤーの水持ちをよくするため，ワイヤーに 1/2"の逆こら配が施された。

紙の地合いをよくするため，ブレストロールより，ワ イヤー・ガイドロール迄，シェーキが行なわた。従っ でサションボックスも同時にシェーキされたのであ
る。

スタッフポンプはプランジャー型で，砲金製球形弁が 使用された。

メーカー 米国 ユニオンマシン社

(9) 明治32年 王子製紙・中部工場

長網抄 紙 機

構成 抄速 $300^{\prime} /$ 分, 網幅 $98^{\prime \prime}$, 新聞用紙

スクリーン 10枚プレートのゴーザム式 $\cdots 2$ 基

ワイヤー 98" $\times 60^{\prime}$, テーブルロール $4^{\prime \prime}$

サクションボックス……4 本

クーチロール 上段 $211 / 8^{\prime \prime}$ (ジャケット巻)

下段 $18^{\prime \prime}$ (ブロンズ)

第1プレス 上段 $24^{\prime \prime}$ 木製 (楓)

下段 $16^{\prime \prime}$ (ゴム巻)

第 2 プレス 上段 $20^{\prime \prime}$ (ブロンズ)

下段 $16^{\prime \prime}$ (ゴム巻)

フェルトは第 2 プレスで反転するよらになっている。

ドライヤー $48^{\prime \prime} \cdots 20$ 本

フェルトドライヤー $36^{\prime \prime} \cdots 4$ 本

ドレーンはサイフォンで抽出された。

カレンダー 10 本立 $\cdots 1$ 基

リール 2 本巻回転式

運転方式 -マーシャル・ドライブで，大きいコーンプ リーはモーチス・ギアで, 小さいコーンプリーは鉄製 であった。また，フリクション・クラッチが付設され ていた。

水車運転で, 変速にはステップ及びコーンプリーが使 用された。

特長 第1プレスに楀を用いて, 湿紙の剥離を容易に した。2 枚スライスが使用された。

シェーキはブレストロールから, 最初のサクション ボックスの手前, 即ち最後のテーブルロール迄振動し, サクションボックスは固定されるよらになっていた。 じ後製作されたシェーキはみなこの型式であった。 メーカー 米国 ブラッククローソン社

(10) 明治41年 4 月 東洋製紙 (後の王子製紙) ・淀 川工場

\section{長網薄紙抄紙機}

構成 網幅 73", シガレットペーパー プレス $\cdots 2$ 基, ドライヤー $5^{\prime} \cdots 1$ 本, $4^{\prime} \cdots 5$ 本 特長 我国最初のシガレット紙抄紙機である。 メーカー スイス エッシャーウイス社

(11) 明治 41 年 5 月 中央製紙（後の樺太工業）中津 工場

長網ティシュー抄紙機 
構成 網幅 $1001 / 2^{\prime \prime}$ ，ドライヤー $\quad 8^{\prime} \cdots 2$ 本

特長 我国最初の長網式ティシュ一抄紙機である。

メーカー 米国 ベロイト社

(12) 明治41年10月 北越製紙・長岡工場

\section{円網板紙抄造機}

構成 網幅 $84^{\prime \prime}$, 黄ボール

シリンダーバット $36^{\prime \prime} \cdots 6$ 本

ドライヤー $\quad 3$-6 6 " $\cdots 35$ 本

カレンダー 7 本立 $\cdots 1$ 基

特長 我国最初の円網式板紙抄造機である。 メーカー 米国 ブラッククローソン社

(13) 明治 43 年 5 月 印刷局抄紙部・十条分工場（後 の王子製紙・十条工場）

\section{長網抄 紙 機}

構成 抄速 $30 \sim 150^{\prime}$ /分, 網幅 $100^{\prime \prime}$

尺坪 8 必まで抄造可能, テーブルロール $31 / 2^{\prime \prime}$

クーチロール 上段 $20^{\prime \prime}$ (ジャケット巻)

下段. $15^{\prime \prime}$ (ブロンズ)

プレスロール３組上段 18”(ブロンズ)

下段 $18^{\prime \prime}$ (ゴム巻)

ドライヤー $54^{\prime \prime} \cdots \cdots 22$ 本

カレンダー 7 本立 $\cdots 1$ 基

運転方式 エンドレスロープによる並列運転で，等速 軸に直立汽機, 変速軸には英国アッシウォース・パー カー社の可変速汽機を使用。

特長 従来スタッフポンプはプランジャ一型であった が，この抄紙機に初めて遠心型が採用された。

大正 7 年頃に，ストーンロールに関する記事が外国 雑誌に紹介されたので，王子製紙ではこの抄紙機に初 めてストーンロールを試用した。じ後王子製紙の各抄 紙機にストーンロールが採用された。

メーカー 英国 バートラム社

(14) 明治 43 年 9 月 王子製紙・苫小牧工場

\section{長 網 抄 紙 機}

構成 抄速 $550^{\prime} /$ 分, 網幅 $142^{\prime \prime}$ ，新聞用紙 スクリーン.12枚プレートのゴーザム式 $\cdots 4$ 基

ワイヤー $142^{\prime \prime} \times 70^{\prime} ，$ テーブルロール $5^{\prime \prime}$

サクションボックス……6本

クーチロール 上段 24" (ジャケット巻)

下段 $26^{\prime \prime}$ (ブロンズ)

プレスロール‥3 基

上段 第 1 ロール及び第 2 ロール $24^{\prime \prime}$ (楓)

上段 第 3 ロール $22^{\prime \prime}$ (ブロンズ)

下段 3 基とも $24^{\prime \prime}$ (ゴム巻)

フェルトは第 3 プレスで反転するよらになっている。
ドライヤー $48 ” \cdots 30$ 本

ドレーンはスクーパーで抽出された。

カレンダー 10 本立 $\cdots 1$ 基

リール 2 本巻回転式

運転方式 マーシャル・ドライブ，モーチスギア使用， ピニオンはカットギア

等速軸は電動機運転，変速軸はコーリスエンジン使用， 建物は二階建で，抄紙機は階上に，運転主軸は階下に 置かれた。

特長 1 枚スライス使用（新聞用紙抄造には 1 枚スラ イスを使用したのは，これが最初である)。

ワイヤーに約 12 "の傾斜がつけられた。

抄造された紙をロールから毛布に移す場合，従来は手 動で操作していたが，抄紙機のスピードが高まって， それでは間に合わなくなり，圧搾空気で吹き飛ばして のせるエア・ノズル方式が採用された。ドライヤー部 にはシェハン（Sheahan）ロープキャリヤー方式が採 用された。

メーカー 米国 バーグレー社

(15) 明治 43 年 9 月 王子製紙・苫小牧工場

\section{円 網 抄 紙 機}

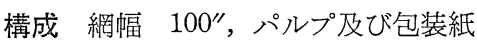

クーチロール $16^{\prime \prime}$

プレスロール…2 基 第 1 組 上段 $18^{\prime \prime}$ (木製)

下段 $18^{\prime \prime}$ (鉄)

第 2 組上段 $18^{\prime \prime}$ (鉄)

下段 $18^{\prime \prime}$ (鉄)

スクイズロール……3 組

ドライヤー 4 "……20本

メーカー 米国 ジェー，コッチ・ホーン社

(16) 明治 45 年 8 月 東京板紙・千住工場

\section{円網板紙抄造機}

構成網幅 $78^{\prime \prime}$ ，黄ボール

シリンダーバット $36^{\prime \prime} \cdots 5$ 本

ドライヤー 36"‥44 本

メーカー 米国 ブラッククローソン社

特長 その後わらを原料とするこの程度の板紙工場が 全国各地に設置された。更にまた小型の幅 36 "程度の 板紙工場も各地に設置された。これは長崎兄弟の計画 によるものといわれている。

大正稫代

(17) 大正 3 年 7 月 王子製紙・苫小牠工場 長 網 抄 紙 機

棈成 抄速 $650^{\prime} /$ 分，網幅 $142^{\prime \prime}$ ，新聞用紙 
スクリーン ホイト社のロー・タリースクリーン

ワイヤーの傾斜 $16^{\prime \prime}$

フェルトは初めて反転なし，ストレートスルー型採用

ドライヤー $4^{\prime} \cdots 34$ 本

リールサーフェースリール

特長 (14)と大体同じ構成であるが，改正された点は， スピードアップのため, ワイヤーの傾斜を $16^{\prime \prime}$ に改め, プレスにストレート・スルー型が採用されたことであ る。

メーカー 米国 バーグレー社

(18) 大正 3 年11月王子製紙・大泊工場 長網パルプ抄造機

構成 ワイヤー $108^{\prime \prime} \times 48^{\prime}$

プレス…2 基 第 1 組 上段 $20.2^{\prime \prime}$ (鋳鉄)

下段 21.7" (ゴム巻)

第 2 組 上段 $23.2^{\prime \prime}$ (鋳鉄)

下段 $23.2^{\prime \prime}$ (ブロンズ）

ドライヤー $49^{\prime \prime} \cdots 14$ 本（後 30 本に改造）

特長 我国最初の長網パルプ抄造機である。その後豊 原, 恵須取, 泊居, 野田, 知取, 落合の各工場にパル プ抄造機が設置されたが，大体大泊のものと同程度で ある。

大正11年，光沢義男氏が海外出張の際，スウェーデ ンでプレスロールにグルーブド・ロールを使用してい るのを知り，帰朝後豊原工場のパルプ抄造機にこれを 採用した。

メーカー スウェーデン カールスタット社

(19). 大正 4 年 中央製紙(後の王子製紙) ・ 中津工場 長網ヤンキー抄紙機

構成 網幅 $100^{\prime \prime}$ ，ドライヤー $10^{\prime}$

特長 我国最初の長網ヤンキー抄紙機である。その後 各地で長網ヤンキー, 長網ティシューが設置されたが, 何れも大同小異で, ドライヤーの直径は $12^{\prime}$ が限度で あった。

メーカー 英国 ベントレー・ジャクソン社

(20) 大正 6 年 11 月 王子製紙・苫小牧工場

\section{長 網 抄 紙 機}

構成 抄速， $750^{\prime} /$ 分，綃幅 $142^{\prime \prime}$ ，新聞用紙

ドライヤー $4^{\prime} \cdots 44$ 本

特長 ドライヤーを増設し, 速度を増加した。プレス パートの占める長さを短縮するため, 地下室が利用さ れた。

メーカー 米国 バーグレー社

(21) 大正 8 年 4 月 王子製紙・十条工場 長網 抄 紙機
構成 幅網 86"，印刷用紙

$$
\begin{aligned}
& \text { スクリーン ドラム式…2台 } \\
& \text { ワイヤー } 86^{\prime \prime} \times 50^{\prime} ， \text { テーブルロール } 3^{\prime \prime} \\
& \text { クーチロール 上段 } 18^{\prime \prime} \text { (ジャケット巻) } \\
& \text { 下段 } 16^{\prime \prime} \text { (ブロンズ) }
\end{aligned}
$$

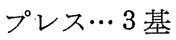

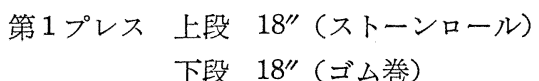

第 2 及び 上段 $\left\{18^{\prime \prime}\right.$ (ブロンズ)

第 3 プレス 下段 $\left\{18^{\prime \prime}\right.$ (ゴム巻)

フェルトは第 2 プレスで反転

ドライヤー $48^{\prime \prime} \cdots 20$ 本

スムーザー ドライヤーの中央部にチルド製スムーザ

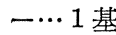

カレンダー 7 本立， 9 本立 $\cdots$ 各 1 基

リール 2 本巻回転式

特長 従来サクションポンプはピストン型であったが， 今回，2 軸回転式が採用された。

米国クロカーバーバンク社では紙面の平滑性をよく するため, 乾燥部の中央にスムーザーを設置し, すこ ぶる好成績であった。スムーザー処理された紙は光沢 がつけ易く，写真版に使用した場合，画像が鮮明に出 るので, 当時の米国の雑誌にはこの用紙が多く使用さ れた。十条工場では今回このスムーザーが採用された。

次に乾燥の調節にフォックスボロ社の自動調節機が 採用され，また抄紙機にスピードメーターが付け加え られた。以上いづれも我国最初の試みであった。 メーカー 米国 バーグレー社

(22) 大正 8 年 12 月，日本紙業・亀有工場

\section{長網 抄 紙 機}

構成 網幅 $120^{\prime \prime}$ ，印刷用紙・包装用紙

特長 サクションクーチロールを設置した。王子製紙 ・中部工場をやめて, 日本紙業・亀有工場へ入社した 塩沢某の発案によるもので, サクションクーチの採用 はこれが我国で最初である。

メーカー 米国 ライスバートン社

(23) 大正 9 年11月、富士製紙・江別工場

\section{長 網 抄 紙 機}

構成 抄速 $800^{\prime} /$ 分，網幅 $186^{\prime \prime}$ ，新聞用紙・ザラ紙 クーチ サクションクーチ

プレス…….... 3 基

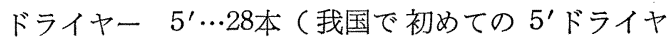
$\rightarrow$

カレンダー 10 本立 $\cdots 1$ 基

特長 江別工場は富士製紙が王子製紙の苫小牧工場に 
対抗して，新聞用紙を目標にして建設した工場であ る。この 186" 抄紙機は当時我国で最大網幅の抄紙機 で, 新聞用紙四六判横 4 枚どりである(142”抄紙機は 四六判横 3 枚どりである)。しかるに当時の新聞社の 輪転機は横の 3.6 尺幅であったので，この幅で差支え なかったが, その後, 新聞社では輪転機の寸法を縦 2 枚どりに改めたので，142"抄紙機は縦 2 枚どりで好 都合であったが，186"抄紙機はサイドランが生じ， 新聞用抄紙機としては不向きであるため，じ後この幅 は採用されなかった。

メーカー 米国 バーグレー社

(24) 大正13年10月 九州製紙(後の樺太工業)・八代 工場

\section{長 網 抄 紙 辢}

構成 抄速 $950^{\prime} /$ 分, 網幅 $142^{\prime \prime}$, 新聞用紙

ワイヤー $142^{\prime \prime} \times 80^{\prime}$ ，テーブルロール 7"

プレスロール……3 基

カレンダー 10 本立 $\cdots 1$ 基

特長 抄紙機の運転方式にセクショナル・ドライブの 方式が採用された。これは米国 GE 社の設計製作にな るものである。また, ワイヤーの迅速取替法が設備さ れた。これらは我国で最初に採用されたものである。 メーカー 米国 バーグレー社

(25) 大正13年-14年 王子製紙・十条工場 ワイヤーの延命対策が次のよらにして行なわれた

(1) ノーデッケル

デッケルはワイヤーの走行につれ回転するゴム製の エンドレスベルトであるため, ベルトに接するワイヤ 一の部分に摩耗を起こし，ワイヤ一の寿命が著しく短 縮する。当時米国の雑誌にデッケルを廃し, 薄い堰板 を固定して，デッケルの代用ができるという記事があ った。十条工場ではこれを採用することとし，ワイヤ 一の両側に堰板を設け，その先端にゴム板を挟み，こ れを軽くワイヤーに接触させることにしたところ，そ の効果は非常によかった。いわゆるノーデッケル方式 である。

(2) サクションボックスカバーの改良

サクションボックスのカバーは近来まで，一般に木 製であった。吸引の際, 木製のカバーではこれに接す るワイヤーの摩耗が甚しかった。ワイヤーの摩耗防止 の改良に熱心であった日本金網株式会社の沖本希三氏 は，このカバーにゴムを用いたところ好結果を得た。 十条工場では沖本氏の考えを採り入れ，前記の不要に なったデッケルストラップのゴムをカバーとして，サ クションボックスに貼りつけて使用したところ，ワイ
ヤーの摩耗は著しく減少した。じ後十場工場の各抄紙 機にもこれが採用された。

(26) 大正14年11月 王子製紙・苫小牧工場 長 網抄紙 機

構成 抄速 $900^{\prime} /$ 分, 網幅 $142^{\prime \prime}$, 新聞用紙 クーチロール サクションクーチを採用 プレス……3 基

ドライヤー $\quad 5^{\prime} \cdots \cdots . .40$ 本

運転方式 英国ハーランド式セクショナルドライブ

特長 我国で初めてストックインレットが採用された。 ワイヤーのこう配は水平，ワイヤーの迅速取替法が設 備された。

新聞用紙抄造にサクションクーチが我国で初めて採 用された。

メーカー 英国 ウォームスレー社

(27) 大正 15 年 12 月 富士製紙・知取工場

\section{長 網 抄 紙 機}

構成 抄速 $1,150^{\prime} /$ 分，網幅 $142^{\prime \prime}$ ，新聞用紙

クーチロール ジャケット巻

プレス……3 基

ドライヤー $\quad 5^{\prime} \cdots \cdots . .44$ 本

運転方式 マーシャル・ドライブで, オイルケースに 入れてあったカットギアを使用，この方式は我国で最 初のものと思われる。

メーカードイッ ホイト社

\section{昭 和 時代}

(28) 昭和元年12月王子製紙・十条工場

\section{長 網 抄 紙 機}

構成 抄速 $150^{\prime} \sim 600^{\prime}$ /分, 網幅 $112^{\prime \prime}$ ，上質紙 ワイヤー $112^{\prime \prime} \times 65^{\prime}$ ，テーブルロール $4^{\prime \prime}$

クーチロール サクションクーチを採用

プレス……3 基

スムーザー ドライヤーの頭部にゴム及びチルド製 スムーザー…1 基

ドライヤー $471 / 4^{\prime \prime} \cdots 30$ 本

カレンダー 8 本立, 10 本立 各 1 基

リール サーフェース・リール

運転方式 マーシャル・ドライブ

特長 抄造品種の変更に応ずるため, ワイヤーの勾配 を上下できるよう設計されたが，後になって水平に固 定された。ワイヤーの摩耗を防ぐため, サクションボ ックス摺動装置が設置された。我国で初めての試みで ある。 
従来ドライヤーの中央部にあったスムーザーをドラ イヤーの頭部に設置した。

メーカー ベルギー チリー社

(29) 昭和 5 年 4 月 王子製紙・十条工場

\section{長 網 抄 紙 機}

構成 抄速 $600^{\prime} /$ 分, 網幅 168”, 中質紙

ワイヤー $168^{\prime \prime} \times 70^{\prime}$ ，テーブルロール $71 / 2^{\prime \prime}$

プレス……3 基

スムーザー ドライヤーの頭部にゴム及びチルド製ス ムーザー…1 基

ドライヤー $5^{\prime} \cdots \cdot \cdots 24$ 本

カレンダー 8 本立, 10 本立…各 1 基

運転方式 ハーランド・セクショナルドライブ

特長 ワイヤーの迅速取替法が設置された。シェーキ は1 カ所で起こさせるのが普通であるが，この抄紙機 ではワイヤーを 2 カ所に分けて振動を起こさせた。こ れによって振動の有効長さを長くした。また振動数も 毎分 400 迄可能にした。

サクションボックス摺動装置が設置された。

メーカー 英国 ウォームスレイ社

(30) 昭和10年12月 王子製紙・都島工場

\section{長網抄 紙 機}

構成，網幅 93"，シガレットペーパー

ワイヤー $93^{\prime \prime} \times 80^{\prime}$

プレス……2 基

ドライヤー $5^{\prime} \cdots \cdots 1$ 本, $4^{\prime} \cdots \cdots 5$ 本

特長 シガレット抄紙機の幅広のものが初めて採用さ れた。

メーカー スイス エッシャーウイス社
(31) 昭和13年 6 月 王子製紙・苫小牧工場

\section{長網抄 紙 機}

構成 抄速 $1,200^{\prime} /$ 分, 網幅 $142^{\prime \prime}$, 新聞用紙 ワイヤーの迅速取替法が採用された。

$$
\begin{aligned}
& \text { クーチロール サクションクーチ } \\
& \text { プレス…… } 3 \text { 基 } \\
& \text { ドライヤー } \quad 5^{\prime} \cdots \cdots \cdot 48 \text { 本 } \\
& \text { カレンダー } \quad 10 \text { 本立 } \cdots \cdot \cdots 1 \text { 基 }
\end{aligned}
$$

運転方式 セクショナル・ドライブ

特長 第1プレスに初めて, サクション式が採用され た。但しブロンズ製でゴムは未だ巻かれなかった。

メーカードイツ ホイト社

\section{以上を総括すると次のようになる。}

\section{1. 我国で最初に採用された各種抄紙機の運転} 年代順に示すと表1の通りである。

2. 抄紙機のスピードアップとテーブルロールにつ いて

抄速，網幅及び長さ，テーブルロールの径を一覽表 にして表 2 に示す。

スピードアップと網幅及び長さの増加に従って, テ ーブルロールの径が大きくなってきたのがよく分る。

\section{3. ワイヤーのこう配について}

明治 23 年，王子製紙王子工場第 2 号機はスピード遅 く，水持ちをよくするため，ワイヤーには $1 / 2^{\prime \prime}$ 逆こ ら配がつけられた。その後王子・苫小牧工場では明治 43年新聞用紙抄造に際し，抄速 $500^{\prime} /$ 分にスピードア

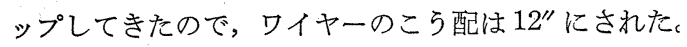

\begin{tabular}{|c|c|c|c|c|}
\hline 運 転 年 月 & 会 社・工 場 & 紙 & 機 & 網 \\
\hline 明治 6 年 & 神 戸製紙所 & 円網 & & $72^{\prime \prime}$ \\
\hline 7 年12月 & 有 恒 社 & 長網 & & $60^{\prime \prime}$ \\
\hline 20年 & 東京板紙・千住 & 長網板紙 & & $74^{\prime \prime}$ \\
\hline 22年 & 王 子・気 田 & 円網ヤンキー & & $72^{\prime \prime}$ \\
\hline 41年 4 月 & 東 洋・淀 川 & *長網薄葉 & & $73^{\prime \prime}$ \\
\hline 41 年 5 月 & 中 央.中 津 & 長網ティシュー & & $1001 / 2^{\prime \prime}$ \\
\hline 41 年 10 月 & 北 越・長 岡 & 円網板紙 & & $84^{\prime \prime}$ \\
\hline 大正 3 年11月 & 王子・大 泊 & パルプマシン & & $108^{\prime \prime}$ \\
\hline 4 年 & 中 央. 中 津 & 長網ヤンキー & & $100^{\prime \prime}$ \\
\hline
\end{tabular}
更に大正 3 年の $142^{\prime \prime}$ 抄紙機では，抄速 $650^{\prime} /$ 分にな うたので，こら配は16"にされた。そして大正14年に

表 1 各種抄紙機最初の運転年月

* 我国最初のシガレット抄紙機 
表 2 抄紙機のスピード, ワイヤー,テーブル・ロールの推移

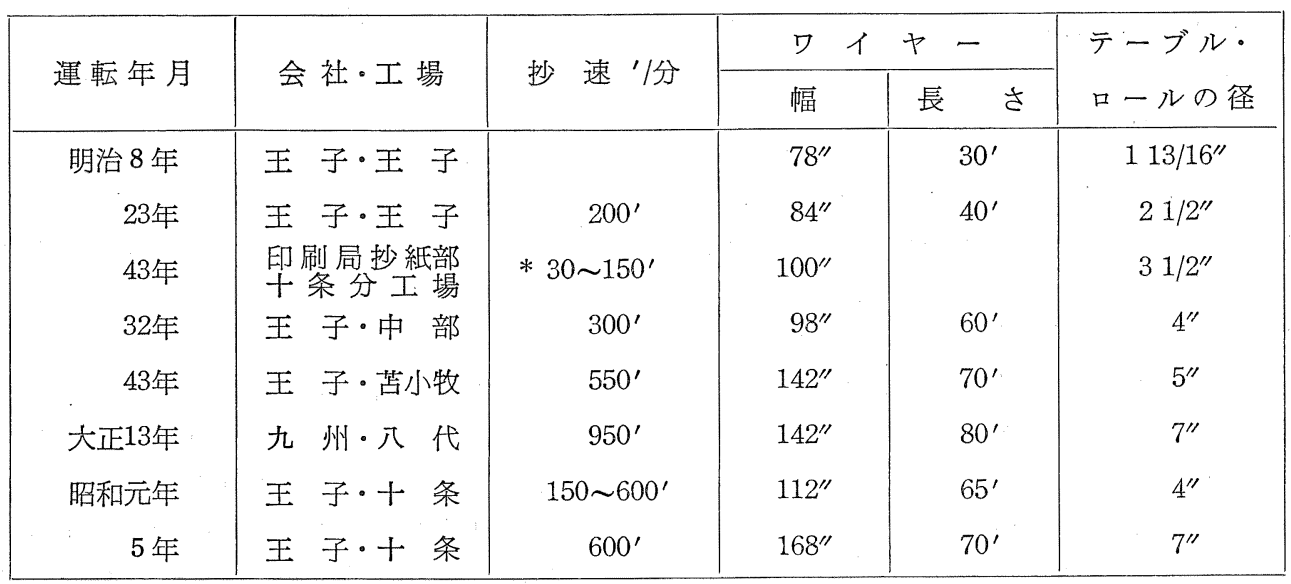

* 大正 7 年 王子・十条工場第 2 号機である。

はストックインレットを採用の結果，フローボックス の水位を調節し得るようになったので，こら配は水平 に改められた。

\section{4. ワイヤーの迅速取替法}

大正12年頃迄は, ワイヤーの取り替えは，一つ一つ のロールをはずして行なっていたので, 大変な手数と 半日にも及ぶ時間的な浪費を払っていた。ところが， 大正13年樺工・八代工場では, 我国で初めてのワイヤ 一迅速取替法が採用された。その結果非常に時間と労 力の浪費が節約されるようになった。

\section{5. ノー・デッケルについて}

大正13年王子・十条工場で初めて採用されたノー・ デッケル方式は, ワイヤーの寿命を長くし，それまで ワイヤーの回転につれ, 回転運行していたデッケルを 廃し, 一種の堰板を定着することによって, 充分所期 の目的を遂行することが出来たのである。それでこの 時代から各社でもこの方式を採用するようになり, 現 在ではデッケルストラップは廃止され, 殆んどノ一。 デッケル方式になっている。

\section{6. クーチロールとサクションボックス}

明治 43 年頃までは，上段クーチロールはジャケット 巻，下段クーチロールはブロンズ製が普通であった。 サクションクーチは大正 8 年日本紙業・亀有工場で採 用され，また大正14年王子・苫小牧工場では新聞用紙 の抄造にサクションクーチを採り入れ，抄紙速度を増 加することが出来た。

大正13年頃，王子・十条工場ではサクションボック スのカバーに初めてゴムを使用し，炤和 5 年にサクシ ョンボックス摺動装置を設置した。共にワイヤーの摩 耗防止に役立った。

\section{7. プレスパートについて}

明治23年王子・王子工場第 2 号機で，書籍用紙抄造 の際，上段プレスロールはブロンズ製であった。しか るに明治 32 年, 王子・中部工場, 更に明治 43 年王子・ 苫小牧工場では新聞用紙抄造の場合には，湿紙のはが れをよくするため，上段プレスロールは共に木製であ った。また同年苫小牧工場では，紙はがしにェア・ノ ズル方式を採用し，抄紙機のスピードアップに対応す ることができた。

大正 3 年, 王子・苫小牧工場では, 従来最後のフェ ルト部は紙を反転して返すようになっていたのを，高 速度になったために，反転すると不便であるので，反 転をやめ, ストレートスルー型を採用した。じ後新聞 戈紙機はこの方式になった。

大正 6 年, プレスパートの占める長さを短縮のため, 地下室が利用された。

大正 7 年頃, 王子・十条工場ではプレスロールに初 めてストーンロールを使用したが，好成績であったの で，じ後でもストーンロールを使用するに至った。 昭和13年，王子・苫小牧工場では我国で初めて第 1 プレスにサクション式を採用した。

\section{8. ドライヤーについて}

王子。王子工場では, 明治 8 年頃には, 給気は表側 より,ドレーンは裏側より抽出していたが, 明治 23 年 第 2 号機より，現在各製紙工場で行なわれている通り 給汽，ドレーン共に裏側より行ならようになった。そ してドレーン抽出は, 初めはサイフォン式であったが, 明治43年，王子・苫小牧工場ではスクーパー式に改め た。その後抄速 $1,000^{\prime} /$ 分になるに及び再度サイフォ ン式に改められた。 
明治43年, シェハンロープキャリヤー方式がドライ ヤ一部に採用され，自動的にドライヤーに紙を通すこ とができた。

\section{9. 運転方式について}

王子・王子工場では明治 8 年, 第 1 号機は英国製で, 運転方式はベルト掛けの並列運転であった。その後印 刷局抄紙部・十条 分工場の $100^{\prime \prime}$ 抄紙機も英国製で, ロープによる並列運転が行なわれた。この並列運転型 式は当時ヨーロッパ製抄紙機には一般に採用された。

ビ後, 我国へ輸入された抄紙機は米国製であったの で，主としてマーシャル・ドライブ型式が採用され た。

大正13年，樺工・八代工場の $950^{\prime} /$ 分 高速新聞抄紙 機には，初めてサクショナル・ドライブが採用され， これを転機として，高速抄紙機運転にはセクショナル

・ドライブが多く採用されるようになった。

大正15年，富士製紙・知取工場の新聞抄紙機の運転
方式はマーシャル型で，オイルケース入りの鋼製カッ ト・ギアが使用された。

結

び

昭和13年以後, 漸次戦時体制に入り, ジャケット, フェルトの入手が困難になってきた。前述のように， サクションクーチ, サクションプレスは, 一部の工場 に初めて採用されたが好成績であったので，各工場の クーチ,プレスをサクション型に改造しょうと企画さ れたがこの時すでに統制経済に入り, 資材の獲得が困 難となったため, 達成ができなかった。これらの改善 は戦後になって初めて行なわれた。

なお, 抄紙機も大型化, 高速化になり, 各部分に種 々の改良, 改善が行なわれた。これら戦後の抄紙機発 展の過程は, 諸君はよくご存知のことと思らからこれ を省略する。

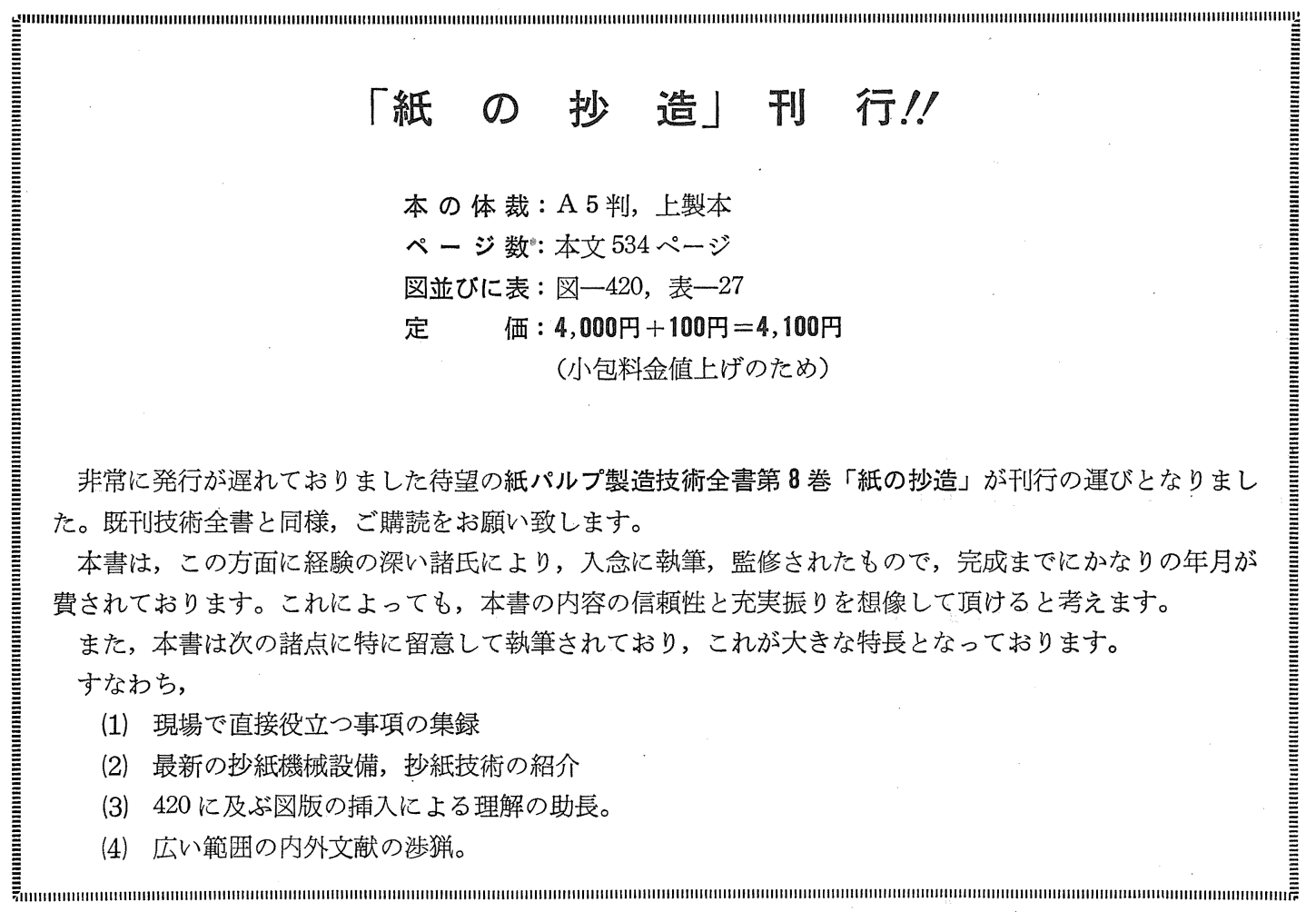

